\title{
Retinoic acid accelerates downregulation of the Xist repressor, Oct4, and increases the likelihood of Xist activation when Tsix is deficient
}

\author{
Janice $Y A h n^{1,2}$, Jeannie T Lee ${ }^{1 *}$
}

\begin{abstract}
Background: Imbalances in X-linked gene dosage between the sexes are resolved by transcriptionally silencing one of two X-chromosomes in female cells of the early mammalian embryo. X-inactivation is triggered by expression of the non-coding Xist gene. In turn, Xist is dually regulated by the antisense Tsix RNA and by the Oct4 pluripotency factor. Although there is general agreement that Tsix is an inhibitor of Xist, some laboratories have observed ectopic Xist induction in differentiating male ES cells when Tsix is mutated, whereas we have not observed significant changes in Xist. These observational differences have led to fundamentally diverse models of $X$-chromosome counting. Here, we investigate if different methods of cell differentiation and use of all -trans retinoic acid (RA) could be causative factors and how they might impact Xist expression.

Results: We compared suspension and cell-adhesion cultures in the presence or absence of RA and find that RA significantly impacts Xist expression in Tsix-mutant male cells. Whereas the standard embryoid body method infrequently leads to ectopic Xist expression, adding RA generates a significant number of Xist-positive male cells. However, while normal Xist clouds in wild-type female cells are robust and well-circumscribed, those found in the RA-treated mutant males are loosely dispersed. Furthermore, ectopic Xist expression does not generally lead to complete gene silencing. We attribute the effect of RA on Xist to RA's repressive influence on Oct4, a pluripotency factor recently shown to regulate Tsix and Xist. RA-treated ES cells exhibit accelerated decreases in Oct4 RNA levels and also display accelerated loss of binding to Xist intron 1. When Tsix is deficient, the faster kinetics of Oct4 loss tip the equilibrium towards Xist expression. However, the aberrant Xist clusters are unlikely to explain elevated cell death, as X-linked silencing does not necessarily correlate with the qualitatively aberrant Xist clusters.

Conclusions: We conclude that RA treatment leads to premature downregulation of Oct4 and partial derepression of Xist irrespective of X-chromosome counting. RA-induced Xist clusters in male cells do not result in global or stable silencing, and excess cell death is not observed. These data and RA's known pleiotropic effects on ES transcription networks suggest that RA differentation bypasses normal X-inactivation controls and should be used judiciously. We propose that the likelihood of Xist expression is determined by a balance of multiple Xist activators and repressors, and that levels of Oct4 and Tsix are crucial toward achieving this balance.
\end{abstract}

\section{Background}

Sex dosage compensation ensures equal X-linked gene expression between $\mathrm{XX}$ and $\mathrm{XY}$ individuals. In mammals, this balance is achieved by transcriptionally silencing an entire $\mathrm{X}$-chromosome in females through a

\footnotetext{
* Correspondence: lee@molbio.mgh.harvard.edu

${ }^{1}$ Howard Hughes Medical Institute Department of Molecular Biology, Massachusetts General Hospital Department of Genetics, Harvard Medical School Boston, MA 02114 USA

Full list of author information is available at the end of the article
}

process called X-chromosome inactivation (XCI) [1]. $\mathrm{XCI}$ is accomplished independently in each cell primarily by the Xist/Tsix pair of sense/antisense non-coding RNAs located within the X-inactivation center $(X i c)$ [2-5]. Xist upregulation and cis-coating of an X-chromosome represent important steps in the $\mathrm{X}$-inactivation process [6,7], and are followed by recruitment of the PRC2 complex [8-10] and other silencing factors to initiate chromosome-wide inactivation and compaction into heterochromatin. Because X-inactivation occurs
Ciomed Central

() 2010 Ahn and Lee; licensee BioMed Central Ltd. This is an Open Access article distributed under the terms of the Creative Commons Attribution License (http://creativecommons.org/licenses/by/2.0), which permits unrestricted use, distribution, and reproduction in any medium, provided the original work is properly cited. 
very early in embryonic development, cell culture models have been developed to facilitate analysis. Female mouse embryonic stem (ES) cells can undergo random $\mathrm{X}$-inactivation when differentiated in vitro [2] and have therefore served as a powerful system with which to study this phenomenon. Xist expression remains low on both Xs in undifferentiated ES cells, but upon differentiation, Xist becomes upregulated only on the future inactive $\mathrm{X}[11,12]$. Xist thus serves as the trigger for the silencing step during the X-inactivation program.

Xist's central nature to XCI has led to intensive investigation of how this gene is regulated. One established regulator is Tsix, the antisense repressor of Xist [13,14]. Tsix RNA is expressed from both Xs in undifferentiated female cells, but its expression becomes monoallelic during the process of cell differentiation and XCI. The chromosome that transiently retains Tsix expression becomes the future active $\mathrm{X}(\mathrm{Xa})$, while the chromosome that extinguishes Tsix expression first becomes the future inactive $\mathrm{X}(\mathrm{Xi})$. Tsix has been proposed to regulate $X$-chromosome pairing, counting, and the mutually exclusive choice of $\mathrm{Xa}$ and $\mathrm{Xi}$ [15-17]. Indeed, various knockouts of Tsix (and its upstream enhancer Xite [18]) have led to nonrandom XCI as well as effects on counting and pairing [13-16].

Although Tsix's repressive role in female cells seems clear, there has been debate over Tsix's role in male cells. The original $3.7 \mathrm{~kb}$ deletion encompassing the major Tsix promoter in male ES cells $\left(T s i x^{\Delta \mathrm{CpG}} / \mathrm{Y}[13]\right)$ did not cause a significant degree of ectopic Xist upregulation upon differentiation $(<1 \%)$. Tsix ${ }^{\Delta \mathrm{CpG}} / \mathrm{Y}$ ES cells were phenotypically normal and capable of generating chimeric mice with germline transmission, and male offspring were born at expected frequencies [13]. This finding led to the conclusion that, whereas Tsix represses Xist, an additional factor - missing in male ES cells and present only in female cells - is required to induce Xist expression in cells with supernumerary $\mathrm{X}$-chromosomes. It was therefore proposed that X-chromosome counting involves two factors: a 'blocking factor' that blocks Xist expression through Tsix on the Xa, and a 'competence factor' that induces Xist expression on $\mathrm{Xi}$ [13].

Significantly, however, other Tsix mutations show variable phenotypes in male cells (Fig. 1). Sado et al. also showed that $T s i x+/$ - female mice can yield viable male offspring carrying the mutation, but $8-21 \%$ of cells isolated from E7.5 male embryos showed ectopic Xist expression, an observation that could be explained by either ectopic Xist expression in the embryo proper or by presence of extraembryonic tissue (which is subject to imprinted XCI and therefore be severely affected by the maternal Tsix deletion) [14]. Another Tsix-specific mutation showed upregulation of Xist RNA in as many as $38 \%$ of differentiating male ES cells in culture $[19,20]$. A $65 \mathrm{~kb}$ deletion of the region $3^{\prime}$ to Xist (including Tsix) also resulted in significant induction of Xist RNA clouds when XO (XLD [21]) or XY (CK35 65 [22]) cells underwent differentiation. Furthermore, smaller mutations including only Tsix elements were also found to have ectopic Xist cloud formation in a subset of differentiating male cells (CK35 $\Delta 34$ and CK35 $\Delta \mathrm{AV}$ [19]). These observations have led to the alternative hypothesis that Xist is activated by default when Tsix is mutated, obviating the need for a competence factor involved in female-specific expression of Xist. Differences with regard to Xist expression in Tsix-deficient male cells (hereafter referred to as $\mathrm{X}^{\Delta} / \mathrm{Y}$ ES cells) have therefore led to fundamentally different models for $\mathrm{X}$-chromosome counting $[3,13,15,22,23]$.

Here, we seek to understand why analyses of male cells in different laboratories should lead to differing results. Although the nature of the mutations could lead to disparate results, another potential difference among the studies might be the method of cell differentiation used to induce XCI. Whereas we differentiate ES cells by the embryoid body method (EB) in the absence of LIF, many laboratories also add retinoic acid (RA) to the differentiation medium. Although some studies have used both the EB and EB+RA methods and found ectopic Xist RNA in both cases [22,24], it remains formally possible that the combination of induction methods, culture conditions, and nature of the mutations could affect the Xist phenotype.

The idea that RA affects Xist expression finds support in two recent studies that demonstrated a role for Oct 4 in repressing Xist by direct and indirect means $[25,26]$. One study showed that Oct4 positively regulates Tsix and that downregulation of Oct4 during cell differentiation triggers $\mathrm{X}$-chromosome pairing, leads to monoallelic repression of Tsix, and consequently enables Xist upregulation on one chromosome [26]. The other study showed that Oct4 also associates with intron 1 of the Xist gene and proposed that Oct4 directly represses Xist [25]. Combined, these studies suggest that Xist is linked to cell differentiation through Oct4's effects on Tsix and Xist. Because it is known that Oct4 is rapidly downregulated in the presence of retinoic acid [27-30] (by binding the regulatory nuclear hormone receptors, RAR and RXR [31]), we consider the possibility that RA treatment to induce cell differentiation may have unanticipated effects on XCI and thereby confound XCI analysis. Here, we set out to test the idea that RA may affect Xist levels through Oct4 by studying one well-charac-

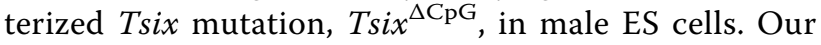
results indicate that differentiation methods indeed influence Xist expression in these ES cells. 


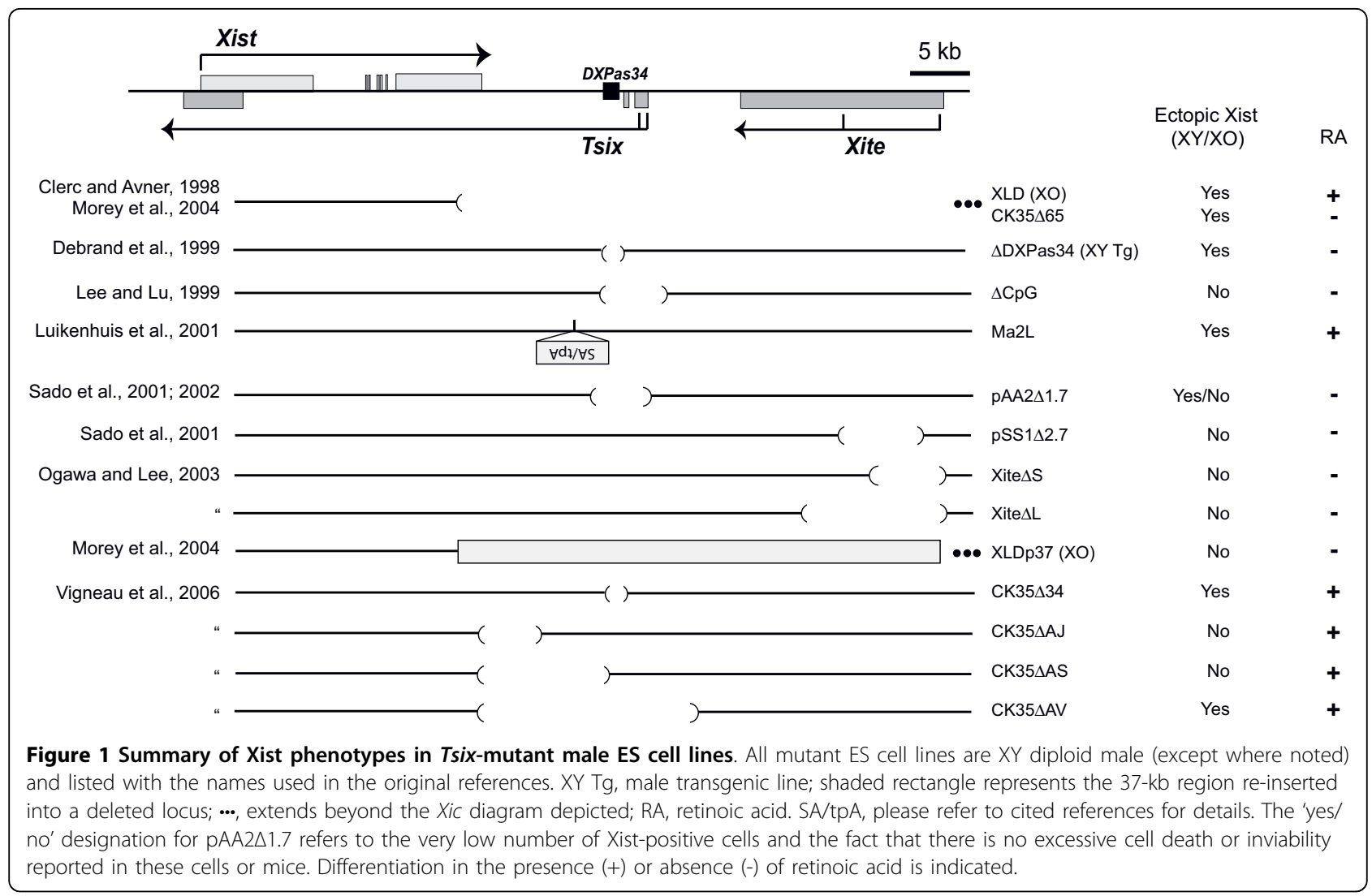

\section{Results}

\section{Ectopic Xist upregulation in $T$ six $^{\Delta C p G}$ male ES cells} differentiated in the presence of retinoic acid

We differentiated wild-type and $T$ six ${ }^{\Delta \mathrm{CpG}}$ male and female ES cells using variations of four published in vitro differentiation techniques: (1) embryoid body formation (EB method), whereby ES cell clusters are cultured in suspension for 4 days, in the absence of LIF, and then plated onto a solid matrix to form EB outgrowths; (2) EB method in the presence of $100 \mathrm{nM}$ of all-trans retinoic acid (EB+RA method); (3) adherent cultures whereby ES cells are plated at low-density on gelatinized tissue culture plates without feeders and LIF (TC method); and (4) TC method in the presence of $100 \mathrm{nM}$ all-trans retinoic acid (TC+RA method).

By Xist RNA FISH (fluorescence in situ hybridization), we detected a slight increase in the percentage of cells with Xist clouds using the embryoid body $(\mathrm{EB})$ versus the low-density cell adhesion (TC) method (Fig. 2A, 32\% in $\mathrm{X} / \mathrm{X}$ EB compared to $18 \%$ in $\mathrm{X} / \mathrm{X}$ TC at day 6 ). Consistent with previous analysis [13], Xist clouds were rare in $\mathrm{X}^{\Delta} / \mathrm{Y}$ cells in the absence of RA $(<2-5 \%, n>200$ cells $)$ and were never observed in wild-type male cells under any differentiation condition and time point examined.

However, while no significant differences were seen for most cell lines between EB and EB+RA or between
TC and TC+RA methods, we did detect differences for $\mathrm{X}^{\Delta} / \mathrm{Y}$ cells (Fig. 2A,B). The differences were significant for all differentiation days (bracketed pairwise comparisons, $P<0.05)$. Ectopic Xist RNA clusters could be seen in $10-30 \%$ of $\mathrm{X}^{\Delta} / \mathrm{Y}$ cells $(n>200)$ when induced to differentiate with RA. The ectopic Xist clouds were almost always more dispersed than wild-type Xist clouds, which are generally intense, compact, and well-defined (Fig. $2 \mathrm{~B}$, lower panels). This observation suggested a problem with either full Xist induction or transcript localization in mutant cells when differentiated with RA. We refer to these abnormal clouds as 'dispersed clusters' to emphasize these qualitative differences from wild-type Xist RNA clouds. X- and Y-chromosome DNA FISH confirmed that all ES cell lines used in this study exhibited the correct XX or XY constitution (Fig. 2C).

We conclude that the method of cell differentiation can impact Xist expression in $\mathrm{X}^{\Delta} / \mathrm{Y}$ ES cells. Specifically, differentiation in the presence of RA leads to the appearance of ectopic Xist clusters only when Tsix is deleted and, when they do appear, the RNA is loosely clustered.

\section{RA induction accelerates loss of Oct4 binding to Xist}

Recent studies suggest that Xist is negatively regulated not only by Tsix but also by Oct $4[25,26]$. Because RA 
A

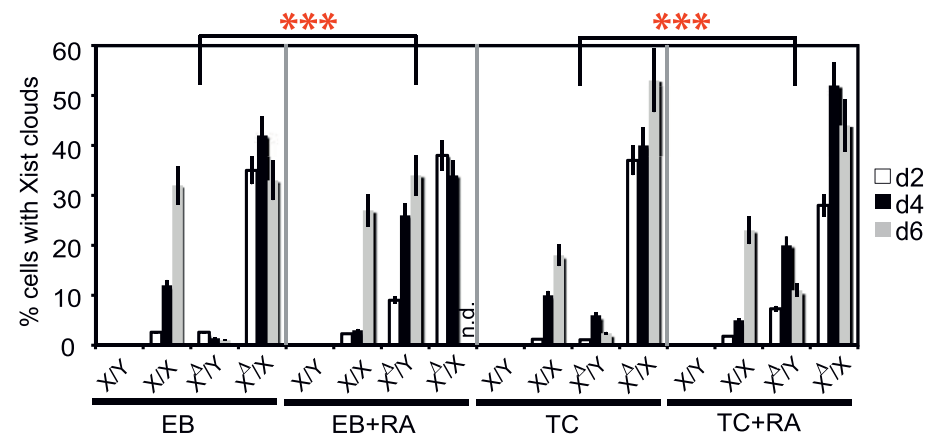

B

$X^{\Lambda} / Y E S$ cells

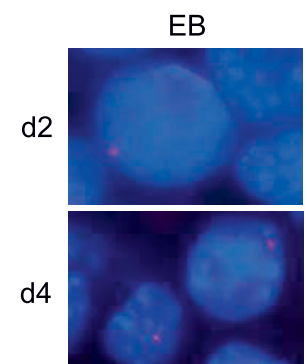

$E B+R A$ TC
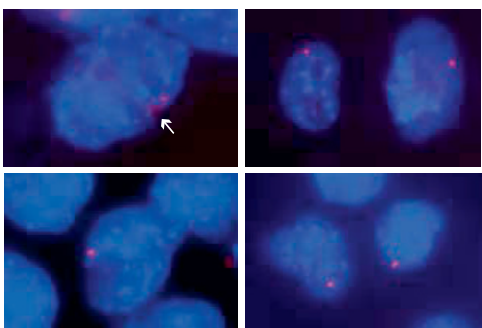

$\mathrm{TC}+\mathrm{RA}$
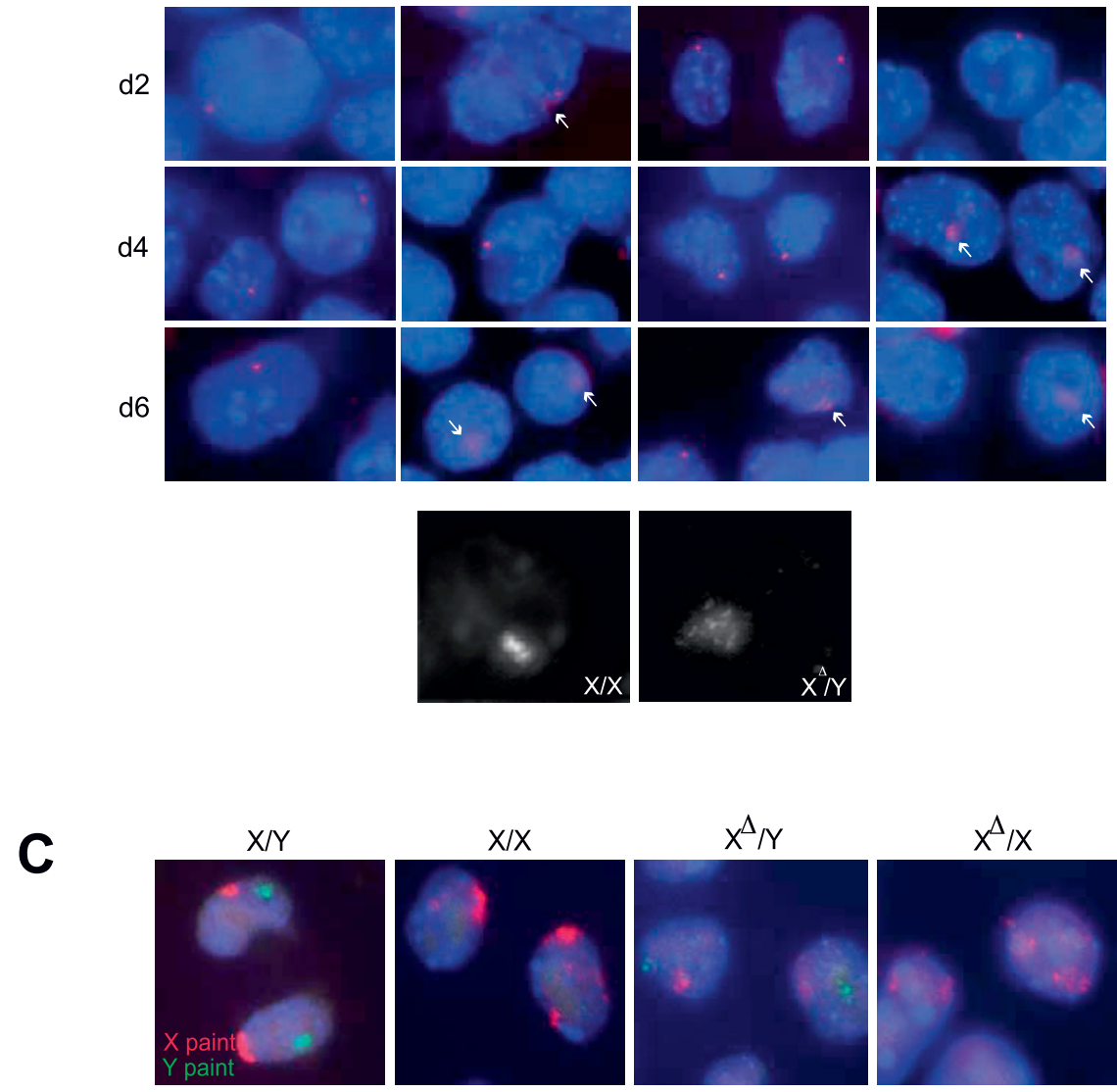

Figure 2 Ectopic Xist RNA clouds observed in Tsix-mutant male ES cells. A. Percentage of cells containing Xist RNA clouds. Note the high percentage of Xist-positive cells in $X^{\Delta} / Y$ cells when differentiated in the presence of RA. Days of differentiation are listed as day 2 (d2), day 4 (d4), and day 6 (d6). Day $6 X^{\Delta} / X$ EB+RA, not determined (n.d.). $X / Y$, wild-type male ES line; $X / X$, wild-type female ES line; $X^{\Delta} / Y, T s i X^{\Delta C p G} / Y$ male $E S$ line; $X^{\Delta} / X$, Tsix ${ }^{\Delta C p G /+}$ female ES line; $n>200$ for each timepoint and cell line examined. Error bars represent the standard deviation from three independent biological replicates. $P$ was calculated by paired, two-tailed Student's $t$-tests. Differences in the number of Xist ${ }^{+}$cells for RA-free versus RA-induced $X^{\Delta} / Y$ cells were statistically significant on all differentiation days (each red asterisk denotes $P<0.05$ for day 2 , day 4 , and day 6 comparisons). EB, EB+RA, TC, and TC+RA conditions are described in the Materials and Methods. B. Xist RNA FISH showing ectopic and diffuse Xist cluster formation (arrows) in differentiating Tsix ${ }^{\Delta C p G}$ male cells. Arrows denote Xist RNA clusters. The RNA FISH probe is double-stranded. Pinpoint signals primarily detect mildly elevated Xist expression in mutant cells caused by the Tsix deficiency, though $\sim 10 \%$ residual Tsix expression from an upstream promoter may also contribute [13]. Below is a side-by-side comparison at day 6 (in grayscale) of a normal compact Xist RNA cloud (X/X, left) next to the ectopic dispersed Xist cluster observed in $X^{\Delta} / Y$ cells (right). $C$. $X$ - and $Y$-chromosome paint confirm that all ES cell lines carry the appropriate number of sex chromosomes. Red, $X$-chromosome; green, $Y$-chromosome. 
has been shown to negatively regulate the murine Oct4 promoter during ES cell differentiation [27-30], we asked if increased Xist expression might be due to accelerated Oct4 loss; i.e., in the absence of the second regulatory arm (Tsix), RA-treated cells would ectopically express Xist. By real-time RT-PCR, we compared relative Xist and Oct4 expression levels in differentiating male ES cells using the four described differentiation methods. In wild-type male cells, Xist was rapidly downregulated upon cell differentiation in a manner that correlated with downregulation of Oct 4 . In $\mathrm{X}^{\Delta} / \mathrm{Y}$ cells differentiated by the EB method, Xist RNA was mildly upregulated upon cell differentiation when Oct4 levels dropped (Fig. 3), but this modest upregulation of Xist did not result in spreading of Xist RNA along the $\mathrm{X}$, consistent with prior findings [13]. Thus, Tsix represses Xist even in male ES cells, but its absence only modestly increases Xist levels [13,14].

Differentiation with RA revealed two differences. First, while wild-type male cells appropriately repressed Xist expression, $\mathrm{X}^{\Delta} / \mathrm{Y}$ ES cells displayed a significant rise in overall Xist RNA levels using the RA method (Fig. 3). This is consistent with the observation that, when differentiated via the EB method, $<2-5 \%$ of $X^{\Delta} / Y$ cells showed Xist clusters, but this percentage increased to $10-30 \%$ in the presence of RA (Fig. 2A). Similar results were obtained for both $\mathrm{EB}+\mathrm{RA}$ and $\mathrm{TC}+\mathrm{RA}$ conditions. At no time of differentiation up to day 6, however, did Xist levels increase by more than 2- to 10-fold in mutant male cells. Thus, Xist upregulation is considerably blunted in RA-induced Tsix-deficient male cells when compared to the 30 - to 100 -fold induction that typically accompanies XCI in normal female cells (data not shown) [13,32-34]. These results showed that RA differentiation led to a higher likelihood of Xist induction in Tsix-deficient male ES cells.

Second, Oct4 downregulation generally occurred more quickly in both wild-type and mutant male ES cells when compared to the same cells grown in the absence of RA (Fig. 3; see pairwise $t$-tests done for each cell line comparing between $\mathrm{EB} / \mathrm{EB}+\mathrm{RA}$ (red asterisks) and $\mathrm{TC} /$ TC+RA (green asterisks)). While Oct4 RNA levels were similar in wild-type and mutant ES cells in the undifferentiated state, differentiation revealed a significant difference in Oct4 mRNA levels at days 4 and/or 6 dependent on whether RA was added to the culture or not. RA accelerated the rate of Oct4 decrease regardless of whether the ES cells were grown as EBs (compare EB versus $\mathrm{EB}+\mathrm{RA}$ ) or as adherent cells (compare TC versus $\mathrm{TC}+\mathrm{RA}$ ). The greatest difference was evident when adherent cells were used. Although Oct 4 mRNA differences are small, cells at this early stage of differentiation

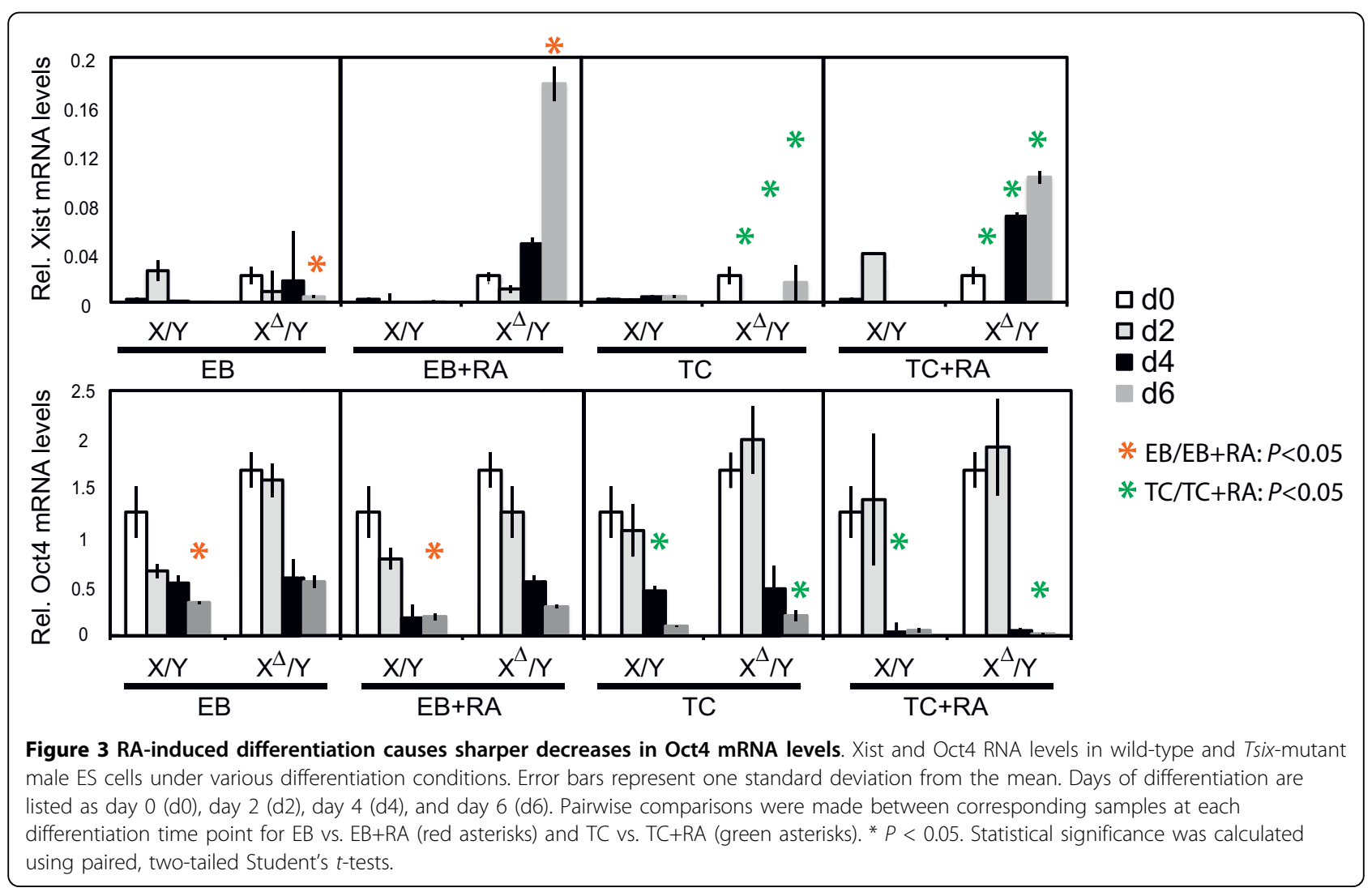


may be more sensitive to subtle changes in levels since a specific range of Oct 4 concentration is required to maintain ES cells as pluripotent stem cells [35]. We note that the cell-adhesion method of differentiation has also been used and shown to form ectopic Xist RNA in Tsix-deficient male cells $[19,22]$.

To determine whether the accelerated overall decrease in Oct4 levels has a direct impact on Xist expression, we asked if the kinetics of Oct4 loss at the Xist locus were altered in RA-containing versus RA-free cultures. Oct4 was previously shown to bind Xist intron 1 in ES cells [25]. It was proposed that Oct4 binding represses Xist in undifferentiated cells and that the loss of Oct4 binding during cell differentiation enables Xist upregulation. We therefore investigated whether cell differentiation triggered by RA might lead to accelerated loss of Oct 4 binding to Xist intron 1 and increased Xist expression. By performing chromatin immunoprecipitations (ChIPs) using $\alpha$-Oct 4 antibodies on wild-type and Tsix-deficient male cells differentiated in parallel, we found that indeed Oct4-binding to Xist intron 1B was lost significantly more quickly when cells were differentiated in the presence of RA (Fig. 4; $P<0.05$, see bracketed pairwise comparisons). We found that indeed Oct4-binding to Xist intron $1 \mathrm{~B}$ was lost significantly more quickly when cells were differentiated in the presence of RA (Fig. $4 ; P<$ 0.05 , see bracketed pairwise comparisons). Differences were evident as early as day 2 . The difference was most evident for WT EB with versus without RA treatment; however, we note that the difference between mutant EB plus versus minus RA treatment might have been masked by somewhat lower Oct 4 binding by $\mathrm{d} 2$. As a negative control, we looked at a region within intron 1 of Xist (intron $1 \mathrm{~A}$, located $0.6 \mathrm{~kb}$ away from intron $1 \mathrm{~B}$ ), which is not known to bind Oct4 [26], and found no statistically significant differences between EB and EB+RA methods. Thus, RA treatment leads to a more rapid loss of Oct4 binding to Xist intron 1 than is typically seen when ES cells are differentiated without RA.

Taken together, these data indicated that RA treatment has little effect on Xist RNA upregulation when Tsix is present, but increases the likelihood with which Xist will be induced when Tsix is deficient. We propose that RA's effect in the absence of Tsix is related to the rapid downregulation of Oct4 by RA, which in turn leads to accelerated loss of Oct4 binding to Xist intron 1. We suggest that, when these events occur in a Tsixdeficient background, Xist is more likely to become derepressed. Overall Oct4 levels are also downregulated in wildtype cells when treated with RA, but the persistence of Tsix would antagonize the derepressive forces. These findings are consistent with the idea that Oct4 and Tsix act in parallel to regulate Xist expression $[25,26]$.

\section{$\mathrm{X}$-chromosome silencing in mutant cells with dispersed Xist clusters}

We next addressed whether the 2- to 10-fold increases in Xist levels and formation of dispersed Xist RNA clusters led to X-chromosome silencing in RA-treated Tsixmutant cells. First, to correlate Xist expression with gene silencing on a cell-by-cell basis, we carried out RNA FISH using probes to simultaneously detect Xist and nascent transcription from the X-linked Pgk1 locus. In wild-type $\mathrm{X} / \mathrm{X}$ cells that have undergone $\mathrm{XCI}$, nascent Pgk1 RNA signals are generally not observed on the $\mathrm{Xi}$, whereas they can be observed in $\sim 60 \%$ on the $\mathrm{Xa}$ at a given time point [13] (Fig. 5A and data not shown). We reasoned that, if ectopic Xist clusters led to gene silencing in $\mathrm{X}^{\Delta} / \mathrm{Y}$ cells, Pgk1 RNA would not be detectable on the Xist-coated $\mathrm{X}^{\Delta}$. On the other hand, if the aberrant Xist clusters could not silence genes in cis, $60 \%$ of $\mathrm{X}^{\Delta}$ would continue to express Pgk1. When differentiated using the RA method, $30 \%$ (21/70) of $X^{\Delta} / Y$ cells with Xist accumulation showed nascent Pgk1 signals (Fig. $5 \mathrm{~A})$, suggesting that complete silencing did not always follow Xist accumulation at this time point, though a fraction of $E B+R A$ cells appeared to undergo inactivation. By contrast, when differentiated using the EB method, $X^{\Delta} / Y$ cells did not express Xist, and Pgk1 expression was observed at the expected frequency of $\sim 60 \%$ (Fig. 5A). Thus, although Xist was partially derepressed by RA treatment of $\mathrm{X}^{\Delta} / \mathrm{Y}$ cells, silencing of genes in cis did not proceed to completion.

With respect to $\mathrm{XCI}$, the $\mathrm{X}$ can be divided into genic versus repetitive element fractions [36,37]. To assess whether repetitive element silencing proceeded to completion, we carried out RNA FISH using probes from the Cot-1 fraction [38], the genomic fraction containing the most highly repetitive elements. In cells where XCI is firmly established, the inactive $\mathrm{X}$ lies either completely or partially within a "Cot-1 hole" (i.e., the inactive $\mathrm{X}$ is depleted for repetitive element expression) [36-39]. In wild-type EB cells on day 6 of differentiation, $22.2 \%$ of Xist clouds lay entirely within a Cot-1 hole and 58.7\% were partially within a Cot-1 hole; only $19 \%$ did not appear to overlap with a Cot-1 hole at all (Fig. 5B). By contrast, in RA-differentiated $\mathrm{X}^{\Delta} / \mathrm{Y} E B, 18.8 \%$ of aberrant Xist RNA clusters were located within a Cot-1 hole and $44.9 \%$ partially within a Cot-1 hole, whereas $36.3 \%$ did not overlap with a Cot-1 hole at all (Fig. 5B). Because the ectopic Xist RNA clusters in $X^{\Delta} / Y$ cells were very diffuse, Xist RNA could often be found in Cot $-1^{+}$regions (and were scored as 'partially within a Cot-1 hole'). Interestingly though, Xist RNA clusters scored as 'entirely within a Cot- 1 hole' appeared more compact, suggesting that perhaps only those cells were able to sufficiently silence their X-chromosomes. Taken together, these results demonstrated that a significant 


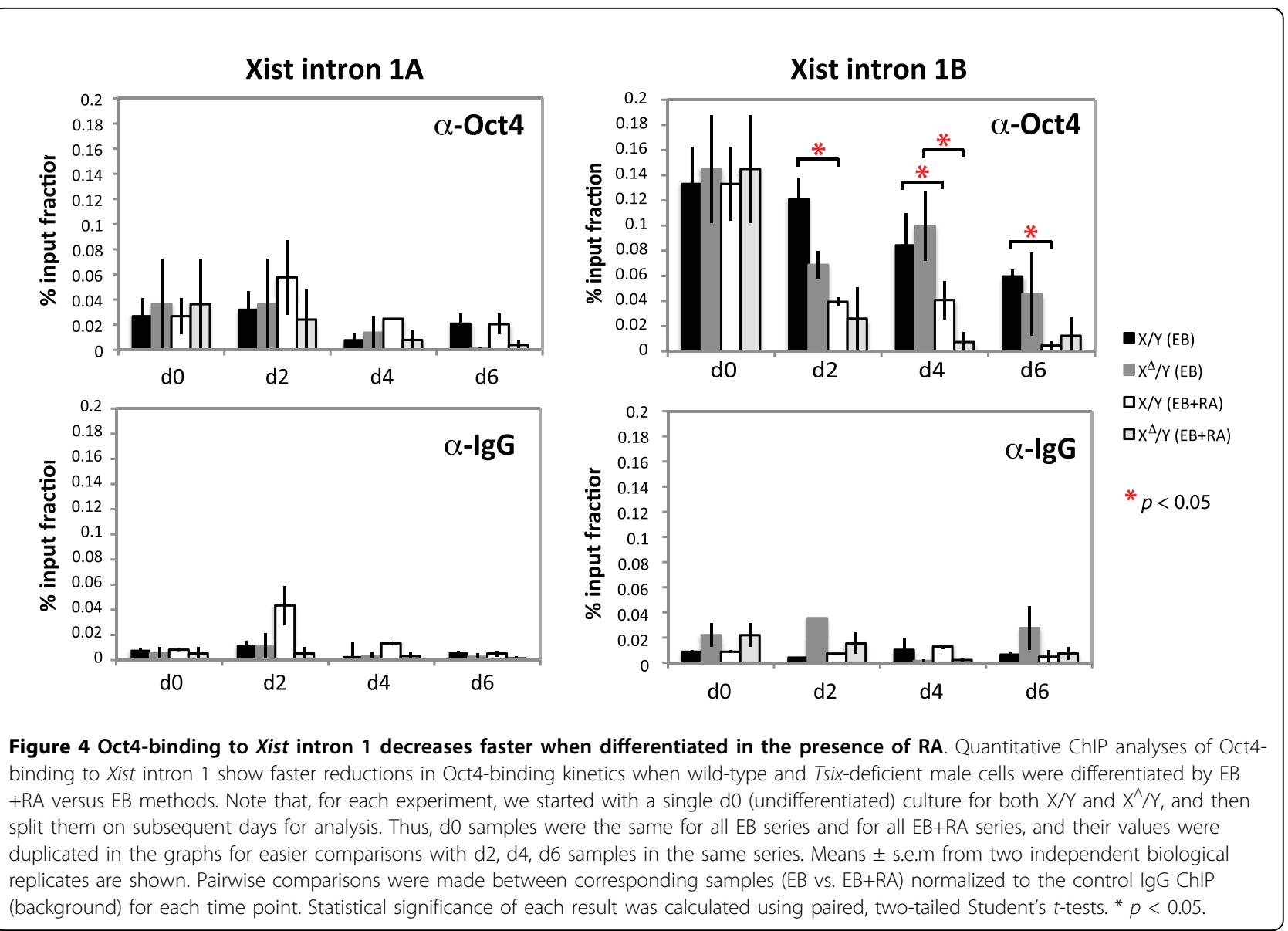

fraction of RA-treated mutant male cells had not completed repeat silencing, suggesting either a delay or a failure to do so. Thus, both genic and repeat silencing were at least partially compromised in $\mathrm{X}^{\Delta} / \mathrm{Y}$ cells with ectopic and diffuse Xist expression induced by RAmediated cell differentiation.

Next we reasoned that, if Xist induction by RA led to $\mathrm{XCI}$ in part, differentiating $\mathrm{X}^{\Delta} / \mathrm{Y}$ cells would show cell death in excess of wild-type cells. However, an equivalent level of cell death was observed for mutant and wild-type cells, suggesting that the $\mathrm{X}^{\Delta}$ chromosome could not have been silenced to a significant extent (Fig. 5C). Notably, regardless of the Tsix genotype, the magnitude of cell death was consistently greater and the population doubling time was substantially slower when cells were differentiated using the RA method (Fig. 5C). Comparison of $E B$ versus $E B+R A$ conditions showed that $<50 \%$ of cells - either wild-type or mutant - survived RA treatment during the first 6 days. Comparison of TC versus TC+RA showed that addition of RA caused a $>95 \%$ drop in cell viability over the same period. These results demonstrate that the Tsix mutation does not have a major effect on the viability of male cells and that RA alone - irrespective of the Tsix deficiency and RA's partial effect on Xist induction - has major effects on cell viability that are unrelated to the XCI pathway. This effect of RA raises the possibility of selection artifacts when mutations are analyzed in the presence of RA.

\section{Discussion}

Here, we have shown that differentiation in the presence of RA results in partial upregulation of Xist RNA when Tsix is deleted in male ES cells. We believe that this results from accelerated loss of Oct 4 and that the depletion of both Tsix and Oct4 (both repressors of Xist) in differentiating ES cells leads to ectopic Xist expression. However, the ectopic Xist clusters appear more dispersed than those typically seen in wild-type female cells, and the degree of Xist activation is an order of magnitude lower. Consistent with these aberrant qualities, the dispersed Xist clusters do not globally or stably silence the male X-chromosome. Thus, RA-induced Xist expression in a Tsix-deficient background does not lead 

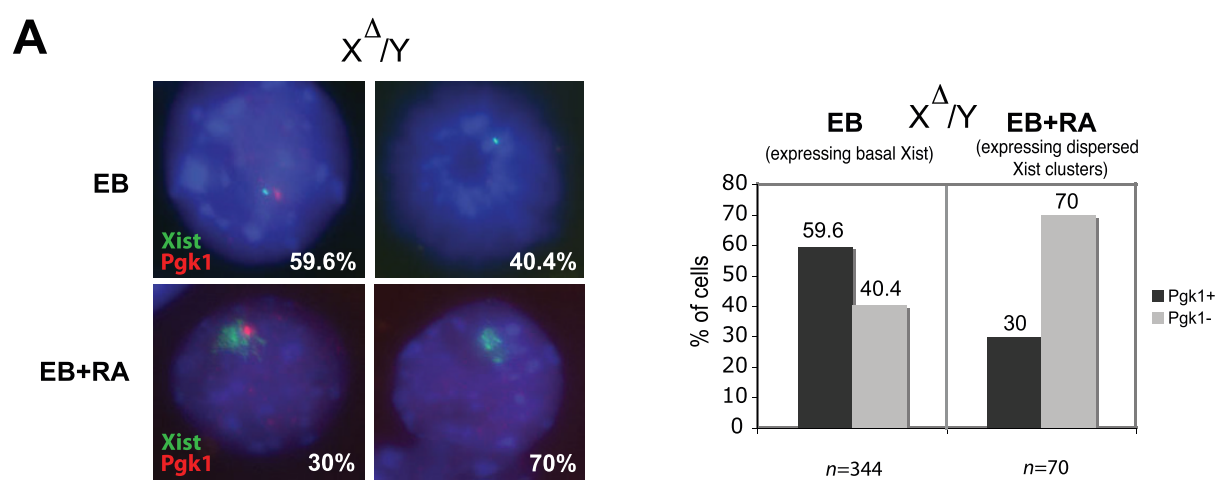

B
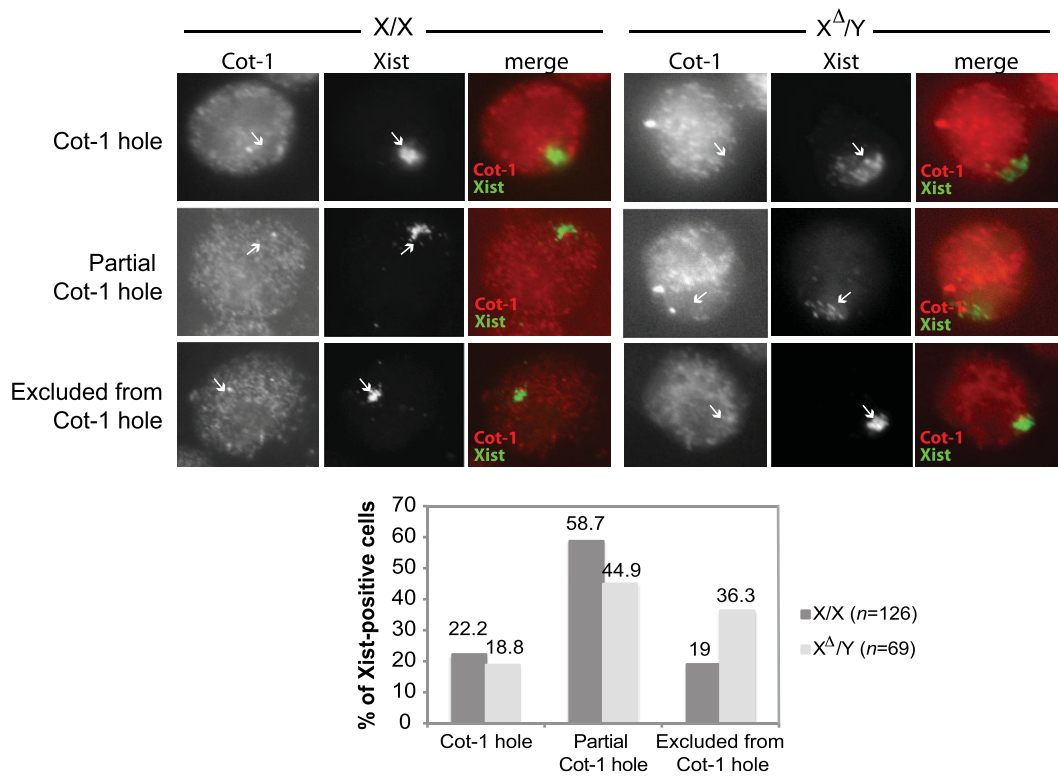

C
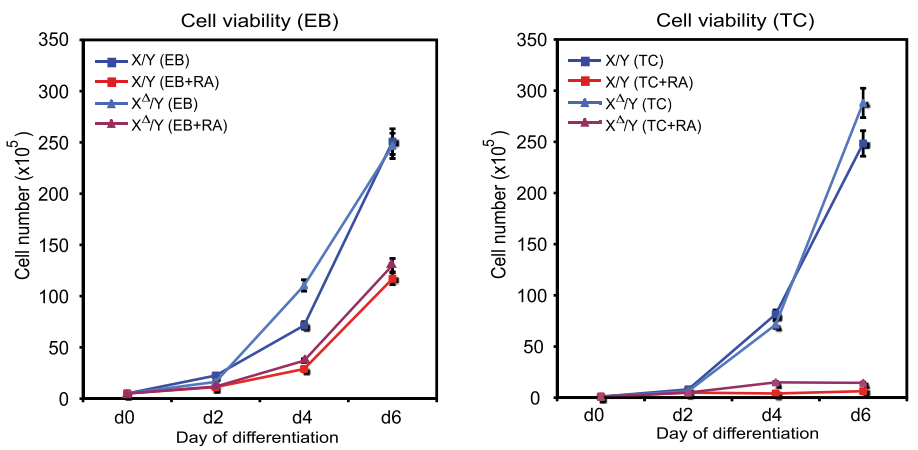

Figure 5 RA-containing cultures lead to silencing of the X-linked gene Pgk1 and exhibit slower overall growth than cultures without RA. A. Xist/Pgk1 RNA FISH showing the percentage of Pgk1 expression in $X^{\Delta} / Y$ cells differentiated under the EB or EB+RA condition at day 6 . EB + RA percentages represent only those cells positive for dispersed Xist RNA clusters. EB percentages represent all cells expressing basal Xist levels. B. Xist/Cot-1 RNA FISH of X/X (EB) and $X^{\Delta} / Y(E B+R A)$ with Xist RNA clouds at day 6 . Percentages represent Xist+ cells that were scored to be located within a Cot-1 RNA hole, partially within a Cot-1 hole, or excluded from a Cot-1 hole, as indicated. Note the higher percentage of Xist clouds excluded from a Cot-1 hole in $X^{\Delta} / Y$ cells when compared to $X / X$ cells. Arrows point to Xist clouds/clusters and their corresponding Cot-1 regions. C. Growth curves for wild-type and Tsix-mutant male cells differentiated under EB/EB+RA (left) or TC/TC+RA (right) conditions. Cultures containing RA (denoted in shades of red) had $<50 \%$ of cells than those cultures grown in the absence of RA (denoted in shades of blue). No differences were seen between $X / Y$ and $X^{\Delta} / Y$ grown under similar conditions. Error bars represent one standard deviation from the mean; days of differentiation are listed as day $0(\mathrm{~d} 0)$, day $2(\mathrm{~d} 2)$, day $4(\mathrm{~d} 4)$, and day $6(\mathrm{~d} 6)$. 
to proper and complete XCI. We also observed that RA treatment uniformly causes massive cell death $(>50 \%)$ regardless of the Tsix genotype. Nonetheless, the fraction of Tsix-deficient male cells that do initiate silencing may be selected against, thus enriching for cells that have not properly initiated XCI. In view of our findings, we suggest that RA differentiation of XCI mutants should be analyzed carefully because RA treatment could either create selection artifacts or indirectly affect XCI through RA's established pleiotropic effects.

It has long been known that RA regulates expression of the POU-domain transcription factor Oct4 (also referred to as Oct3/4 and Pou5f1), which is restricted to pluripotent stem cells and is downregulated when induced to differentiate by treatment with RA [27-30]. RA and other vitamin A derivatives have pervasive effects on developmental processes-including vertebrate embryogenesis, growth, differentiation, and homeostasis-primarily through binding to the RAR and RXR nuclear hormone receptors [31]. RAR isoforms mediate transcriptional activation through binding of either 9-cis or all-trans RA [40,41], while RXRs $(\alpha, \beta, \gamma)$ work specifically through 9-cis-RA [31,42-44]. These receptors form homo- or heterodimeric complexes and bind RAresponsive elements in target genes to transcriptionally mediate expression [45-49]. Oct4 is regulated at the level of transcription [35] through binding of RARs [50], chick ovalbumin upstream promoter transcription factors (COUP-TFs) [51], germ cell nuclear factor (GCNF), as well as other proteins [52], to upstream enhancer regions (designated DE and $\mathrm{PE}$ for distal and proximal enhancers, respectively) [50] and an Sp1 site [53] located within the Oct4 promoter. Upon RA-induced differentiation, these specific factors bind to and downregulate Oct4 in ES and EC cells [50,51,54]. It is possible that these genome-wide and pleiotropic effects of RA would have indirect effects on XCI, which might thereby explain differences in the Xist phenotype observed in our Tsix-deficient background from those of others.

Xist differences in EB- versus RA-differentiated cultures can be summarized by the model shown in Figure 6. Our model supposes that Xist is independently repressed by Oct 4 and Tsix. In undifferentiated wildtype male ES cells (Fig. 6A), high levels of Oct4-along with Nanog and Sox2-bind within intron 1 of the Xist gene $[25,26]$ and keep Xist expression at a "basal" level ( $<10$ copies per cell) $[8,55,56]$. Oct 4 also binds to Tsix/ Xite to transactivate antisense transcription (not shown), which in turn also represses Xist [25,26]. During differentiation into EBs, Oct4 expression decreases slowly and remains high enough during early differentiation to maintain Xist repression. At the same time, persistent Tsix expression stably switches off Xist ("off" state) [33,55,57-59]. This early stage corresponds to the reversible Xist-dependent time window for XCI [60]. Later during differentiation, Oct4 is significantly downregulated, Tsix is extinguished, and Xist is safely and stably repressed, possibly by a transcriptional gene silencing (TGS)-like mechanism and by DNA methylation of the Xist promoter [59,61] (after the Xist-dependent time window [60]). Under conditions of RA-induced differentiation and accelerated loss of Oct4, the outcome would be similar, as Tsix ensures continued repression of Xist.

In $\mathrm{X}^{\Delta} / \mathrm{Y}$ cells, the outcome would be different (Fig. 6B). Ordinarily, the rapid drop in Oct4 levels during RAinduced differentiation would have little impact on Xist, as an intact Tsix would suppress full Xist activation. However, deletion of Tsix would eliminate the second arm of Xist regulation, resulting in ectopic Xist expression. The increase in Xist expression would be modest, would not yield robust Xist clouds, and would not necessarily be followed by chromosome-wide inactivation, explaining why we did not observe a noticeable increase in cell death.

Although we prefer this model, we cannot exclude other potential explanations for the behavior of $T s i x^{\triangle C P G} / \mathrm{Y}$ cells in general. It is clear that the Xist promoter is not properly silenced in RA-differentiated Tsixmutant male cells. Therefore, it is possible that a very small minority of $T s i x^{\Delta C p G} / \mathrm{Y}$ cells that initiate XCI during the early time window (when the $\mathrm{Xi}$ can be established) are selected against and are rarely observed. Because Xist is not properly silenced in the absence of Tsix, cells might continue to upregulate Xist at later stages and form improper and abnormal Xist RNA clusters, which would not be capable of silencing the X. These cells might then survive longer and be observed by our assay. Although this scenario is possible, we do not believe that it can explain the observations related to RA made in this study. Firstly, ectopic Xist expression is rarely observed without RA treatment. Secondly, in the presence of RA, Xist RNA clusters are actually observed during the early time window during the silencing-competent phase of XCI. Thus, we believe that the more likely explanation is the one offered in Figure 6.

Interestingly, the percentage of RA-differentiated cells with ectopic Xist upregulation in a Tsix-mutant background is similar among other studies and our own ( $10 \%$ at day 2$)[19,20,22]$. Our results are also consistent with those reported by Navarro et al. for an Oct4null male ES line. Although these authors reported that Xist upregulation was not seen in Oct4-null male ES cells when differentiated by retinoic acid alone [25], this line contained a tetracycline-repressible Oct4 transgene which lacked the endogenous Oct4 promoter and upstream enhancer regions (PE and $\mathrm{DE})$. As the retinoic acid repressible elements $[50,62]$ are located within this region, their Oct4-null male line would not be directly affected by RA treatment. 
A

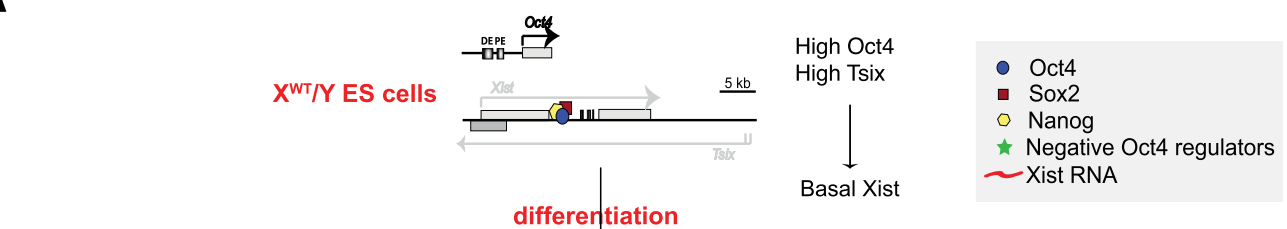

early

High Oct4

PersistentTsix<smiles>[CH]1[CH][AsH2]CC1</smiles>

Oct4 bound, Persistent Tsix

$=$ Xist off

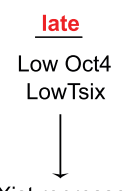

Xist repressed<smiles>CC(C)C</smiles>

RA
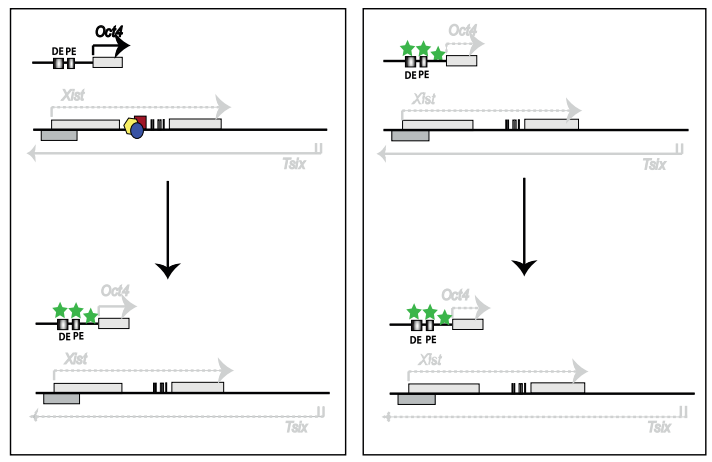

early

RARs bind Oct4 $=$ low Oct 4

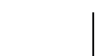

Persistent Tsix

= Xist off

late

Xist repressed
B

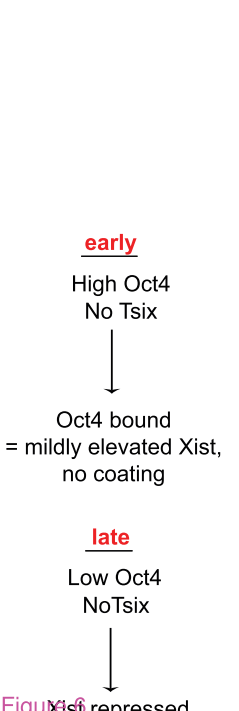

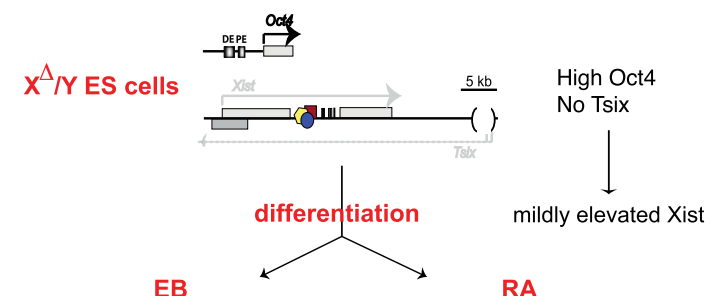
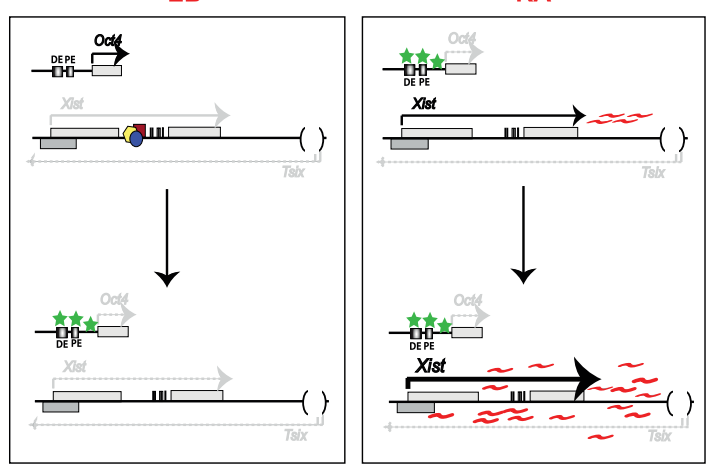

early

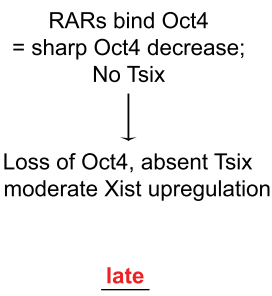

Xist derepression; dispersed clusters

Figure 6 Model of RA-induced Xist expression in Tsix-mutant male cells. A. Undifferentiated wild-type X/Y cells maintain high levels of Oct4, Sox2, and Nanog, which bind to Xist intron 1. This synergistic binding - in addition to high Tsix RNA expression - effectively suppresses Xist. Under the EB differentiation method (left), Oct4 expression remains high early during differentiation, allowing continued binding of Oct4, Sox2, and Nanog to keep Xist off. Although Oct4 levels and binding decrease during late differentiation, Xist continues to remain repressed as the Xist-dependent phase of $\mathrm{XCl}$ has passed. Under the RA differentiation method (right), RA binds to its receptor to form RAR complexes, which then bind to and negatively regulate Oct4. However, persistent Tsix expression maintains stable Xist repression. B. In undifferentiated $X^{\Delta} / Y$ cells, high levels of Oct4, Sox2, and Nanog are sufficient to repress Xist in the absence of Tsix. Under the EB differentiation method (left), Oct4 expression remains high early during differentiation, allowing continued binding of Oct4, Sox2, and Nanog to maintain low Xist expression even in the absence of Tsix transcription. Although Oct4 mRNA levels and binding to Xist intron 1 decrease during late differentiation, Xist is stably repressed as the Xist-dependent phase has passed. However, in the RA differentiated state (right), RAR complexes bind to Oct4, causing premature Oct4 downregulation; loss of Oct4 binding to Xist intron 1 and absence of Tsix lead to moderate Xist upregulation during the early (Xist-dependent) stages of differentiation. Due to Xist derepression during this early stage and lack of antisense Tsix transcription, Xist RNA starts to accumulate and diffusely coats the chromosome in cis, leading to formation of visible Xist RNA clusters and incomplete silencing. DE and PE refer to distal and proximal Oct4 enhancers, respectively. 
Our results suggest that the likelihood of Xist expression is determined by a balance of multiple Xist activators and repressors, consistent with other proposed models [13,15,23,63-65]. Deletion, mutation or downregulation of repressive factors would predispose that $\mathrm{X}$-chromosome to inactivation, but would ordinarily not lead to ectopic inactivation in male cells when other repressors are present. Thus, deletion of the Tsix locus alone in male cells would prevent binding of XCI repressive factors to the single $\mathrm{X}$-chromosome but not lead to ectopic inactivation. However, the absence of Tsix in combination with premature loss of Oct4-binding to Xist intron 1 due to RA-induced differentiation in $\mathrm{Tsix}^{\Delta \mathrm{CpG}} / \mathrm{Y}$ male cells would be sufficient to derepress Xist expression independently from this sensing mechanism.

This idea may explain why some investigators have observed the appearance of Xist clusters even when Tsix-deficient cells were differentiated using the EB method. In our hands, $T s i x^{\Delta \mathrm{CpG}} / \mathrm{Y}$ ES cells rarely show Xist clusters $(<5 \%)$. Sado et al. have reported that the $T s i x^{\mathrm{pAA} 2 \Delta 1.7} / \mathrm{Y}$ mutant shows slightly more Xist clusters during early differentiation by the EB method ( 10\%) $[14,24]$, which may be explained by the severity of this Tsix mutation. The Tsix ${ }^{\mathrm{pAA} 2 \Delta 1.7}$ mutation is a severe truncation mutation with lethality being highly penetrant in the mouse [14,24], whereas the Tsix ${ }^{\triangle \mathrm{CPG}}$ mutation shows $\sim 10 \%$ residual antisense expression and shows lower penetrance of lethality in mice $[13,66]$. The combination of a severe $T s i x^{\mathrm{PAA} 2 \Delta 1.7}$ mutation with RAaccelerated Oct4 depletion could explain why Xist upregulation is more frequently seen than in the case for our Tsix ${ }^{\Delta \mathrm{CpG}}$ mutation. The $65 \mathrm{~kb}$ deletion of Avner and colleagues yields an even greater number of $\mathrm{Xist}^{+}$cells when differentiated into EBs $[19,22]$. Because the $65 \mathrm{~kb}$ deletion includes all of the $5^{\prime}$ end of Tsix and Xite and deletes two of the three known Oct4-binding sites within the Xic $[25,26]$, we propose that combining it with accelerated decreases in both RA-induced Oct4 transcription and binding would further increase the likelihood of Xist expression.

\section{Conclusions}

We argue that the moderate elevation of Xist RNA levels in RA-treated $X^{\Delta} / Y$ cells is not due to aberrant Xchromosome counting but to premature Oct4 downregulation and accelerated loss of Oct4-binding to Xist intron 1. RA also has general pleiotropic effects on transcription that could further affect the XCI process. Our observations suggest that cells lacking Tsix - when differentiated under more physiological conditions (such as that simulated by LIF withdrawal and formation of EBs) - remain capable of suppressing Xist and preserving viability. These ideas are consistent with the two-factor model, which proposes that a repressive "blocking" factor and an activating "competence" factor coordinately regulate the $\mathrm{X}$-chromosome counting process $[13,15]$. By this model, Xist RNA is induced and XCI is initiated only when the blocking factor is not bound in cis and a competence factor (expressed only in $\mathrm{X} / \mathrm{X}$ cells) is present. Both $X / Y$ and $X^{\Delta} / Y$ cells would lack the competence factor and be incapable of fully initiating XCI even if Tsix and the blocking factor were eliminated. Apart from the consequences shown here, RA's acceleration of Oct4 downregulation would also be expected to alter the timing of $\mathrm{X}$-chromosome pairing, an event proposed to regulate $\mathrm{X}$-chromosome counting, and thereby account for why different studies observe pairing on different differentiation days $[16,17]$. Relevantly, Oct4 has been shown to control the timing of X-chromosome pairing [26]. We suggest, therefore, that RA should be used judiciously in studies of X-chromosome counting and other events surrounding the initiation of XCI.

\section{Methods}

\section{ES cell lines and culture}

Wild-type male (J1), female (EL16.7), and Tsix-mutant (CG7 male and 3F1 female) ES cell lines and culture conditions have been previously described [13].

\section{ES cell differentiation}

Each ES cell line was differentiated for six days using one of the following differentiation methods: (1) suspension cultures forming embryoid bodies (EB), (2) suspension cultures forming EBs $+100 \mathrm{nM}$ of all-trans retinoic acid (EB+RA), (3) cells plated at low density on $0.2 \%$ gelatinized tissue culture plates (TC), and (4) cells plated at low density on $0.2 \%$ gelatinized tissue culture plates + $100 \mathrm{nM}$ all-trans retinoic acid (TC+RA). LIF (leukemia inhibitory factor) was removed in all differentiation methods. $\mathrm{EB}$ and $\mathrm{EB}+\mathrm{RA}$ cultures had a starting concentration of $\sim 5 \times 10^{5}$ cells $/ 60 \mathrm{~cm}^{2}$, while TC and TC+RA cultures had a starting concentration of $\sim 1 \times 10^{5}$ cells/ $60 \mathrm{~cm}^{2}$. Culture medium was changed every two days, and $100 \mathrm{nM}$ all-trans retinoic acid was added fresh where appropriate. All-trans retinoic acid (Sigma Cat \# R2625) was diluted in DMSO as $10 \mathrm{mM}$ stock solutions, stored in light-protected vials at $-20^{\circ} \mathrm{C}$, and diluted in culture media just prior to use. All experiments were performed three times. Viable cells were counted using a Cellometer Auto cell counter (Nexcelom Biosciences).

\section{RNA fluorescence in situ hybridization}

ES cells were trypsinized into single cells, cytospun onto glass slides, fixed in $4 \%$ paraformaldehyde/1xPBS, and FISH was carried out as described [13]. Xist, $P g k 1$, and Cot-1 RNA were detected using double-stranded DNA 
probes labeled with Cy3-dUTP or FITC-dUTP either by nick-translation (Roche) or using the Prime-It Fluor Fluorescence Labeling Kit (Stratagene). Digital images were taken with a Nikon Eclipse 90i microscope (Nikon Instruments, Inc.) and processed using Volocity software (Improvision). In brief, $z$-sections were captured at 0.2 $\mu \mathrm{m}$ intervals, and 3-D images were projected onto a single 2-D plane. Cells were counted and scored for the presence or absence of an Xist cloud or cluster. X-and $Y$-chromosome paint was performed on undifferentiated cells as previously described [67] using StarFISH Cy3or FITC-labeled probes from Cambio.

\section{Real-time RT-PCR}

Total cellular RNA was isolated from TRIzol reagent (Invitrogen) by phenol/chloroform extraction and treated with TURBO DNase (Ambion). RNA $(1 \mu \mathrm{g})$ was reverse transcribed into cDNA with random hexamers using the SuperScript III First-Strand Synthesis System (Invitrogen) following the manufacturer's instructions. Real-time PCR was performed on a Bio-Rad iCycler machine with SYBR-Green iQ Mix (Bio-Rad). After an initial denaturation at $95^{\circ} \mathrm{C}$ for $8: 30 \mathrm{~min}$, reactions were amplified for 40 cycles: $95^{\circ} \mathrm{C}$ for $30 \mathrm{~s}, 58^{\circ} \mathrm{C}$ for $30 \mathrm{~s}$, $72^{\circ} \mathrm{C}$ for $30 \mathrm{~s}$, followed by dissociation curve analyses at $55^{\circ} \mathrm{C}$ for $1 \mathrm{~min}$ and $55^{\circ} \mathrm{C}+0.5^{\circ} \mathrm{C}$ every $20 \mathrm{~s}$. Xist primers amplified exons 1-3 of the cDNA and were as follows: NS66, 5'-GCTGGTTCGTCTATCTTGTGGG-3' and NS33, 5'-CAGAGTAGCGAGGACTTGAAGAG-3' [34]. Oct 4 and GAPDH primers were as follows: Oct4F, 5'-GAAGCAGAAGAGGATCACCTTG-3'; Oct4R, 5'TTCTTAAGGCTGAGCTGCAAG-3'; GAPDH1F, 5'ATGAATACGGCTACAGCAACAGG-3'; GAPDH1R, 5'-CTCTTGCTCAGTGTCCTTGCTG-3'. All primers were added at a final concentration of $200 \mathrm{nM}$. The $\mathrm{Ct}$ (defined as the cycle number at which the fluorescence exceeds the threshold value) was determined for each reaction run in triplicate, and relative-fold differences were calculated using the $2^{-\Delta \Delta C t}$ method normalized to GAPDH levels and female fibroblasts (for Xist) or undifferentiated ES cells (for Oct4) as a reference sample [68].

\section{Chromatin immunoprecipitations (ChIPs)}

ChIP analyses were carried out using a modified protocol from Millipore, and the results were averaged for two independent biological replicates of wild-type and $\mathrm{Tsix}^{\Delta \mathrm{CpG}}$ male cells at day 0 , day 2 , day 4 , and day 6 of differentiation; error bars denote standard errors of the means.

\section{Chromatin isolation}

Briefly, $1-2 \times 10^{7}$ cells were trypsinized into a single-cell suspension and crosslinked with formaldehyde to a final concentration of $1 \%$ at $37^{\circ} \mathrm{C}$ for $10 \mathrm{~min}$. Crosslinking was quenched with glycine (125 $\mathrm{mM}$ final), and cells were pelleted at $640 \mathrm{~g}$ for $5 \mathrm{~min}$ and washed twice with $1 \times$ phosphate buffered saline containing protease inhibitors (Roche mini cOmplete protease inhibitor cocktail tablets, EDTA-free \#11-836-170-001). Nuclei were isolated from fixed cells by washing once with Buffer ANP-40 (5 mM PIPES, pH 8.0, $85 \mathrm{mM} \mathrm{KCl,} \mathrm{0.5 \%} \mathrm{NP-40),}$ incubated on ice for $10 \mathrm{~min}$, then washed with Buffer A (5 mM PIPES, pH 8.0, $85 \mathrm{mM} \mathrm{KCl}$ ) and Lysis Buffer (10 $\mathrm{mM}$ Tris- $\mathrm{HCl}, \mathrm{pH} 8.0,10 \mathrm{mM} \mathrm{NaCl}, 3 \mathrm{mM} \mathrm{MgCl}_{2}$, $0.5 \% \mathrm{NP}-40)$. Pelleted nuclei were resuspended in MNase buffer (10 mM Tris- $\mathrm{HCl}, \mathrm{pH} 8.0,10 \mathrm{mM} \mathrm{NaCl}$, $3 \mathrm{mM} \mathrm{MgCl}_{2}, 1 \mathrm{mM} \mathrm{CaCl}_{2}, 4 \% \mathrm{NP}-40$ ) containing protease inhibitors and 1\% SDS. Lysates were sonicated using the Bioruptor XL (Diagenode) [15 min total with $30 \mathrm{~s}$ on- and $30 \mathrm{~s}$ off-cycles]. Sonicated lysates were centrifuged at $16,100 \mathrm{~g}$ for $10 \mathrm{~min}$, and the supernatants were stored at $-80^{\circ} \mathrm{C}$.

\section{Immunoprecipitation}

All IP steps were performed at $4^{\circ} \mathrm{C}$. For each immunoprecipitation, $50 \mu \mathrm{l}$ of Dynal Protein G-magnetic beads (Invitrogen \# 100-04D) were first incubated with $5 \mu \mathrm{g}$ of appropriate antibody for 2 hours with rotation, then with sonicated supernatants $\left(\sim 2.0 \times 10^{6}\right.$ cells $)$ overnight. IP samples were washed twice each with Low Salt TSE 150 (20 mM Tris- $\mathrm{HCl}, \mathrm{pH}$ 8.0, 0.1\% SDS, $1 \%$ Triton X100, $2 \mathrm{mM}$ EDTA, $150 \mathrm{mM} \mathrm{NaCl}$ ), High Salt TSE 500 (20 mM Tris- $\mathrm{HCl}, \mathrm{pH} 8.0,0.1 \%$ SDS, $1 \%$ Triton X-100, $2 \mathrm{mM}$ EDTA, $500 \mathrm{mM} \mathrm{NaCl}), \mathrm{LiCl}$ Buffer $(10 \mathrm{mM}$ Tris$\mathrm{HCl}, \mathrm{pH}$ 8.0, $250 \mathrm{mM} \mathrm{LiCl}, 1 \% \mathrm{NP}-40,1 \%$ deoxycholate, $1 \mathrm{mM}$ EDTA), and TE Buffer (10 mM Tris- $\mathrm{HCl}, \mathrm{pH}$ 8.0, $1 \mathrm{mM}$ EDTA). Protein/antibody complexes were eluted from the beads with freshly made Elution Buffer (50 mM Tris- $\mathrm{HCl}, \mathrm{pH}$ 8.0, $1 \mathrm{mM}$ EDTA, 1\% SDS, $50 \mathrm{mM} \mathrm{NaHCO} 3$ ) incubated at $65^{\circ} \mathrm{C}$ for $10 \mathrm{~min}$. Crosslinks were reversed by digestion with $80 \mu \mathrm{g}$ proteinase $\mathrm{K}$ at $65^{\circ} \mathrm{C}$ for 4 hours, and DNA was recovered by phenol/ chloroform extraction.

ChIP antibodies included goat polyclonal anti-Oct4 (Santa Cruz \#sc8628) and normal rabbit IgG (Cell Signaling \#2729). Quantitative PCR was performed using an iCycler iQ real-time PCR detection system (Bio-Rad) with primers specific to Xist intron 1 (site A: p63/p64, distanced $0.6 \mathrm{~kb}$ from site $\mathrm{B}$ : p65/p66). Primer sequences were as follows: p63, 5'-CTGAAGATGGTGATGGCGAGTTG-3'; p64, 5'-AAAGAGTTCCCCAAATTAGTGTCCTG-3'; p65, 5'-ATGTTTCCTT TTGAAGCAGTTACTTGTAC-3'; p66, 5-CATTGTCTG GCTCTCTAGGTGATAATAC-3' [26]. Pairwise comparisons were made between corresponding samples (EB vs. EB+RA) normalized to the control IgG ChIP (background) for each time point. Statistical significance of each result was calculated using a paired, two-tailed $t$-test. ${ }^{*} p<0.05$ 


\section{Acknowledgements}

We would like to thank all members of the Lee lab for stimulating discussion and helpful comments. This work was supported by the National Institutes of Health [RO1-GM58839] to JTL and the Michael and Anna Vranos Graduate Fellowship Fund in the Life Sciences to JYA. JTL is an investigator of the Howard Hughes Medical Institute.

\section{Author details}

${ }^{1}$ Howard Hughes Medical Institute Department of Molecular Biology, Massachusetts General Hospital Department of Genetics, Harvard Medical School Boston, MA 02114 USA. ${ }^{2}$ Department of Molecular and Cellular Biology, Harvard University Cambridge, MA 02138 USA.

\section{Authors' contributions}

JYA performed all of the experiments. JYA and JTL designed the experiments, analyzed the data, and wrote the paper. All authors read and approved the final manuscript.

Received: 7 February 2010 Accepted: 20 August 2010 Published: 20 August 2010

\section{References}

1. Lyon MF: Gene action in the X-chromosome of the mouse (Mus musculus L.). Nature 1961, 190:372-373.

2. Payer $\mathrm{B}$, Lee JT: $\mathbf{X}$ chromosome dosage compensation: how mammals keep the balance. Annu Rev Genet 2008, 42:733-772.

3. Avner $P$, Heard E: X-chromosome inactivation: counting, choice and initiation. Nat Rev Genet 2001, 2:59-67.

4. Lucchesi JC, Kelly WG, Panning B: Chromatin remodeling in dosage compensation. Annu Rev Genet 2005, 39:615-651.

5. Wutz A, Gribnau J: X inactivation Xplained. Curr Opin Genet Dev 2007, 17:387-393.

6. Clemson CM, McNeil JA, Willard HF, Lawrence JB: XIST RNA paints the inactive $X$ chromosome at interphase: evidence for a novel RNA involved in nuclear/chromosome structure. J Cell Biol 1996, 132:259-275.

7. Penny GD, Kay GF, Sheardown SA, Rastan S, Brockdorff N: Requirement for Xist in X chromosome inactivation. Nature 1996, 379:131-137.

8. Zhao J, Sun BK, Erwin JA, Song JJ, Lee JT: Polycomb proteins targeted by a short repeat RNA to the mouse $\mathrm{X}$ chromosome. Science 2008, 322:750-756.

9. Plath K, Fang J, Mlynarczyk-Evans SK, Cao R, Worringer KA, Wang H, de la Cruz CC, Otte AP, Panning B, Zhang Y: Role of histone H3 lysine 27 methylation in $X$ inactivation. Science 2003, 300:131-135

10. Silva J, Mak W, Zvetkova I, Appanah R, Nesterova TB, Webster Z, Peters AH, Jenuwein T, Otte AP, Brockdorff N: Establishment of histone h3 methylation on the inactive $\mathrm{X}$ chromosome requires transient recruitment of Eed-Enx1 polycomb group complexes. Dev Cell 2003, 4:481-495.

11. Martin GR, Epstein CJ, Travis B, Tucker G, Yatziv S, Martin DW Jr, Clift S, S C: $X$-chromosome inactivation during differentiation of female teratocarcinoma stem cells in vitro. Nature 1978, 271:329-333.

12. Rastan $\mathrm{S}$, Robertson $\mathrm{E}: \mathrm{X}$ chromosome deletions in embryo-derived (EK) cell lines associated with the lack of $X$ chromosome inactivation. Embryol Exp Morphol 1985, 90:379-388.

13. Lee JT, Lu N: Targeted mutagenesis of Tsix leads to nonrandom $\mathrm{X}$ inactivation. Cell 1999, 99:47-57.

14. Sado T, Wang Z, Sasaki H, Li E: Regulation of imprinted X-chromosome inactivation in mice by Tsix. Development 2001, 128:1275-1286.

15. Lee JT: Regulation of X-chromosome counting by Tsix and Xite sequences. Science 2005, 309:768-771.

16. Xu N, Tsai CL, Lee JT: Transient homologous chromosome pairing marks the onset of $X$ inactivation. Science 2006, 311:1149-1152.

17. Bacher CP, Guggiari M, Brors B, Augui S, Clerc P, Avner P, Eils R, Heard E: Transient colocalization of $X$-inactivation centres accompanies the initiation of $X$ inactivation. Nat Cell Biol 2006, 8:293-299.

18. Ogawa $Y$, Lee JT: Xite, $X$-inactivation intergenic transcription elements that regulate the probability of choice. Mol Cell 2003, 11:731-743.

19. Vigneau S, Augui $S$, Navarro $P$, Avner $P$, Clerc P: An essential role for the DXPas34 tandem repeat and Tsix transcription in the counting process of X chromosome inactivation. Proc Natl Acad Sci USA 2006, 103:7390-7395.
20. Luikenhuis S, Wutz A, Jaenisch R: Antisense transcription through the Xist locus mediates Tsix function in embryonic stem cells. Mol Cell Biol 2001, 21:8512-8520.

21. Clerc $P$, Avner P: Role of the region $3^{\prime}$ to Xist exon 6 in the counting process of X-chromosome inactivation. Nat Genet 1998, 19:249-253.

22. Morey C, Navarro P, Debrand E, Avner P, Rougeulle C, Clerc P: The region $3^{\prime}$ to Xist mediates $\mathrm{X}$ chromosome counting and H3 Lys-4 dimethylation within the Xist gene. Embo J 2004, 23:594-604.

23. Monkhorst K, Jonkers I, Rentmeester E, Grosveld F, Gribnau J: X inactivation counting and choice is a stochastic process: evidence for involvement of an X-linked activator. Cell 2008, 132:410-421.

24. Sado T, Li E, Sasaki H: Effect of TSIX disruption on XIST expression in male ES cells. Cytogenet Genome Res 2002, 99:115-118.

25. Navarro P, Chambers I, Karwacki-Neisius V, Chureau C, Morey C, Rougeulle C, Avner P: Molecular coupling of Xist regulation and pluripotency. Science 2008, 321:1693-1695.

26. Donohoe ME, Silva SS, Pinter SF, Xu N, Lee JT: The pluripotency factor Oct4 interacts with Ctcf and also controls X-chromosome pairing and counting. Nature 2009, 460:128-132

27. Scholer HR, Balling R, Hatzopoulos AK, Suzuki N, Gruss P: Octamer binding proteins confer transcriptional activity in early mouse embryogenesis. Embo J 1989, 8:2551-2557.

28. Okamoto K, Okazawa H, Okuda A, Sakai M, Muramatsu M, Hamada H: A novel octamer binding transcription factor is differentially expressed in mouse embryonic cells. Cell 1990, 60:461-472

29. Rosner MH, Vigano MA, Ozato K, Timmons PM, Poirier F, Rigby PW, Staudt LM: A POU-domain transcription factor in early stem cells and germ cells of the mammalian embryo. Nature 1990, 345:686-692.

30. Schoorlemmer J, Kruijer W: Octamer-dependent regulation of the kFGF gene in embryonal carcinoma and embryonic stem cells. Mech Dev 1991, 36:75-86.

31. Allenby G, Bocquel MT, Saunders M, Kazmer S, Speck J, Rosenberger M, Lovey A, Kastner P, Grippo JF, Chambon P, et al: Retinoic acid receptors and retinoid $X$ receptors: interactions with endogenous retinoic acids. Proc Natl Acad Sci USA 1993, 90:30-34

32. Morey C, Arnaud D, Avner P, Clerc P: Tsix-mediated repression of Xist accumulation is not sufficient for normal random $X$ inactivation. Hum Mol Genet 2001, 10:1403-1411.

33. Sheardown SA, Duthie SM, Johnston CM, Newall AE, Formstone EJ, Arkell RM, Nesterova TB, Alghisi GC, Rastan S, Brockdorff N: Stabilization of Xist RNA mediates initiation of X chromosome inactivation. Cell 1997, 91:99-107.

34. Stavropoulos N, Lu N, Lee JT: A functional role for Tsix transcription in blocking Xist RNA accumulation but not in X-chromosome choice. Proc Natl Acad Sci USA 2001, 98:10232-10237.

35. Ovitt CE, Scholer HR: The molecular biology of Oct- 4 in the early mouse embryo. Mol Hum Reprod 1998, 4:1021-1031.

36. Namekawa SH, Payer B, Huynh KD, Jaenisch R, Lee JT: Two-step imprinted $\mathrm{X}$-inactivation: Repeat vs genic silencing in the mouse. $\mathrm{Mol}$ Cell Biol

37. Clemson CM, Hall LL, Byron M, McNeil J, Lawrence JB: The X chromosome is organized into a gene-rich outer rim and an internal core containing silenced nongenic sequences. Proc Natl Acad Sci USA 2006, 103:7688-7693.

38. Hall LL, Byron M, Sakai K, Carrel L, Willard HF, Lawrence JB: An ectopic human XIST gene can induce chromosome inactivation in postdifferentiation human HT-1080 cells. Proc Natl Acad Sci USA 2002, 99:8677-8682.

39. Huynh KD, Lee JT: Inheritance of a pre-inactivated paternal $\mathrm{X}$ chromosome in early mouse embryos. Nature 2003, 426:857-862.

40. Kastner P, Perez A, Lutz Y, Rochette-Egly C, Gaub MP, Durand B, Lanotte M, Berger $R$, Chambon P: Structure, localization and transcriptional properties of two classes of retinoic acid receptor alpha fusion proteins in acute promyelocytic leukemia (APL): structural similarities with a new family of oncoproteins. Embo J 1992, 11:629-642.

41. Chambon P: The molecular and genetic dissection of the retinoid signalling pathway. Gene 1993, 135:223-228.

42. Heyman RA, Mangelsdorf DJ, Dyck JA, Stein RB, Eichele G, Evans RM, Thaller C: 9 -cis retinoic acid is a high affinity ligand for the retinoid $X$ receptor. Cell 1992, 68:397-406.

43. Levin AA, Sturzenbecker L, Kazmer S, Bosakowski T, Huselton C, Allenby G, Speck J, Kratzeisen C, Rosenberger M, Lovey A, et al: 9-cis retinoic acid 
stereoisomer binds and activates the nuclear receptor RXR alpha. Nature 1992, 355:359-361.

44. Mangelsdorf DJ, Borgmeyer U, Heyman RA, Zhou JY, Ong ES, Oro AE, Kakizuka A, Evans RM: Characterization of three RXR genes that mediate the action of 9-cis retinoic acid. Genes Dev 1992, 6:329-344.

45. Yu VC, Delsert C, Andersen B, Holloway JM, Devary OV, Naar AM, Kim SY, Boutin JM, Glass CK, Rosenfeld MG: RXR beta: a coregulator that enhances binding of retinoic acid, thyroid hormone, and vitamin $D$ receptors to their cognate response elements. Cell 1991, 67:1251-1266.

46. Bugge TH, Pohl J, Lonnoy O, Stunnenberg HG: RXR alpha, a promiscuous partner of retinoic acid and thyroid hormone receptors. Embo J 1992, 11:1409-1418.

47. Kliewer SA, Umesono K, Heyman RA, Mangelsdorf DJ, Dyck JA, Evans RM: Retinoid $\mathrm{X}$ receptor-COUP-TF interactions modulate retinoic acid signaling. Proc Natl Acad Sci USA 1992, 89:1448-1452.

48. Leid M, Kastner P, Lyons R, Nakshatri H, Saunders M, Zacharewski T, Chen JY, Staub A, Garnier JM, Mader S, et al: Purification, cloning, and RXR identity of the HeLa cell factor with which RAR or TR heterodimerizes to bind target sequences efficiently. Cell 1992, 68:377-395.

49. Marks MS, Hallenbeck PL, Nagata T, Segars JH, Appella E, Nikodem VM, Ozato K: H-2RIIBP (RXR beta) heterodimerization provides a mechanism for combinatorial diversity in the regulation of retinoic acid and thyroid hormone responsive genes. Embo J 1992, 11:1419-1435.

50. Pikarsky E, Sharir H, Ben-Shushan E, Bergman Y: Retinoic acid represses Oct-3/4 gene expression through several retinoic acid-responsive elements located in the promoter-enhancer region. Mol Cell Biol 1994, 14:1026-1038.

51. Schoorlemmer J, van Puijenbroek A, van Den Eijnden M, Jonk L, Pals C, Kruijer W: Characterization of a negative retinoic acid response element in the murine Oct4 promoter. Mol Cell Biol 1994, 14:1122-1136.

52. Gu P, LeMenuet D, Chung AC, Mancini M, Wheeler DA, Cooney AJ: Orphan nuclear receptor GCNF is required for the repression of pluripotency genes during retinoic acid-induced embryonic stem cell differentiation. Mol Cell Biol 2005, 25:8507-8519.

53. Marin M, Karis A, Visser P, Grosveld F, Philipsen S: Transcription factor Sp1 is essential for early embryonic development but dispensable for cell growth and differentiation. Cell 1997, 89:619-628.

54. Sylvester I, Scholer HR: Regulation of the Oct-4 gene by nuclear receptors. Nucleic Acids Res 1994, 22:901-911.

55. Sun BK, Deaton AM, Lee JT: A transient heterochromatic state in Xist preempts $\mathrm{X}$ inactivation choice without RNA stabilization. Mol Cell 2006 21:617-628.

56. Buzin $\mathrm{CH}$, Mann JR, Singer-Sam J: Quantitative RT-PCR assays show Xist RNA levels are low in mouse female adult tissue, embryos and embryoid bodies. Development 1994, 120:3529-3536.

57. Panning $B$, Dausman J, Jaenisch $R: X$ chromosome inactivation is mediated by Xist RNA stabilization. Cell 1997, 90:907-916.

58. Navarro P, Pichard S, Ciaudo C, Avner P, Rougeulle C: Tsix transcription across the Xist gene alters chromatin conformation without affecting Xist transcription: implications for X-chromosome inactivation. Genes Dev 2005, 19:1474-1484.

59. Ogawa Y, Sun BK, Lee JT: Intersection of the RNA interference and Xinactivation pathways. Science 2008, 320:1336-1341.

60. Wutz A, Jaenisch $\mathrm{R}$ : $\mathrm{A}$ shift from reversible to irreversible $\mathrm{X}$ inactivation is triggered during ES cell differentiation. Mol Cell 2000, 5:695-705.

61. Sado T, Hoki Y, Sasaki H: Tsix silences Xist through modification of chromatin structure. Dev Cell 2005, 9:159-165.

62. Minucci S, Botquin V, Yeom YI, Dey A, Sylvester I, Zand DJ, Ohbo K, Ozato K, Scholer HR: Retinoic acid-mediated down-regulation of Oct3/4 coincides with the loss of promoter occupancy in vivo. Embo J 1996, 15:888-899.

63. Monkhorst K, de Hoon B, Jonkers I, Mulugeta Achame E, Monkhorst W, Hoogerbrugge J, Rentmeester E, Westerhoff HV, Grosveld F, Grootegoed JA, Gribnau J: The probability to initiate $X$ chromosome inactivation is determined by the $X$ to autosomal ratio and $X$ chromosome specific allelic properties. PLoS One 2009, 4:e5616.

64. Starmer J, Magnuson T: A new model for random X chromosome inactivation. Development 2009, 136:1-10.

65. Jonkers I, Barakat TS, Achame EM, Monkhorst K, Kenter A, Rentmeester E, Grosveld F, Grootegoed JA, Gribnau J: RNF12 is an X-Encoded dose- dependent activator of $\mathrm{X}$ chromosome inactivation. Cell 2009, 139:999-1011.

66. Lee JT: Disruption of imprinted $\mathrm{X}$ inactivation by parent-of-origin effects at Tsix. Cell 2000, 103:17-27.

67. Panning B, Jaenisch R: DNA hypomethylation can activate Xist expression and silence X-linked genes. Genes Dev 1996, 10:1991-2002.

68. Livak KJ, Schmittgen TD: Analysis of relative gene expression data using real-time quantitative PCR and the 2(-Delta Delta C(T)) Method. Methods 2001, 25:402-408.

doi:10.1186/1471-213X-10-90

Cite this article as: Ahn and Lee: Retinoic acid accelerates downregulation of the Xist repressor, Oct4, and increases the likelihood of Xist activation when Tsix is deficient. BMC Developmental Biology 2010 10:90.

\section{Submit your next manuscript to BioMed Central and take full advantage of:}

- Convenient online submission

- Thorough peer review

- No space constraints or color figure charges

- Immediate publication on acceptance

- Inclusion in PubMed, CAS, Scopus and Google Scholar

- Research which is freely available for redistribution

Submit your manuscript at www.biomedcentral com/submit
C Biomed Central 